CADERNO DE POESIA I

Isaac Ramos ${ }^{1}$

\title{
CARDÁPIO LÍRICO
}

Sirva-me tua concha molhada de versos

Sirva-me um verbo lambuzado de gestos

Sorva-me em gotas como delírios poéticos

Embriaga-te com lírios

Enquanto tocas liras inconfessas.

\section{CASCATAS}

O rio serpenteia a lua imaculada

No regaço da noite a mancha do néctar

Deságua cascatas em nádegas alvoradas.

\section{CONCHAS DE SILÊNCIO}

Visto a praia com conchas de silêncio

Solto um grito de verso

Que escorre

Nas areias do meu deserto...

O oásis contagia-me de sinestesias.

\section{DOCE METÁFORA}

O teu canto é uma nota solta

O teu grito uma carícia frouxa

$\mathrm{O}$ teu pranto uma gota louca

Mas o que mais admiro em você

É esse incrivel sabor de metáfora.

1 Poeta e ensaísta. Doutorando em Estudos Comparados de Literaturas de Língua Portuguesa. FFLCH-USP. 


\section{Ó DIA DA CRIAÇÃO}

Deus criou o mundo, os sonhos e o paraíso

Mas, por via das dúvidas, reservou o inferno

Para os pecadores e para os poetas

O purgatório ele destinou

Aos bedéis

E o céu (que novidade!)

Aos que não se impregnaram de fel.

Nenhuma costela retirada de Adão

Justificou até hoje ritmos dissolutos

Nenhum pedaço mordido da maçã

Ajudou a consertar rimas perdidas

Nenhum ser feito de pó

Ao pó voltará sem ter feito a lição

Por isso, trair, coçar e comentar...

Nem os poetas escapam desse estrupício!

Ó ritmo altissonante!

Ó turba de carpideiras!

Vibrem estoicamente sobre a tumba

Desses versos fagueiros

Senhor Deus dos desgraçados!

Zele pelas viúvas sem xale

Olhe pelas mulheres desenganadas

Sem cor, sem pudicícia, sem nada

Porque, como diria Vinicius,

Os homens não prestam, não prestam!...

Mas emplastram prazeres de graça.

Senhor Deus dos alucinados!

Oriente os enfermos que sofreram baixas

Nas suas paixões tácitas

Repreenda todos os casados de plantão

Que se dizem solteiros

Incrimine todos os homens

Que não cederam uma de suas costelas

Para formar o suposto par perfeito

E se ainda assim

Alguma paixão encubada sobreviver

Risque do mapa Sodoma e Gomorra

$\mathrm{E}$ afogue todos em mágoas

Num tonel de vinho do Porto.

Ó musas bacantes,

Desejem todos os homens errantes!

Digníssimas amadas e amantes,

Sejam manjares para olhos vibrantes 
Todavia cuidado com os espíritos de sicofantas

E o que dizer para os apaixonados periclitantes?

Sejam passiveis sem serem irritantes

Enfim, poetas alcoviteiros

Sirvam a Baco, Dionísio e Helena

Mas não se esqueçam do barqueiro

Porque ele cobra o dobro

Sobre o gozo alheio.

Ó divino dia da criação!...

Benditas sejam as metáforas

Que escorreram nos seios da poesia adúltera

Benditos sejam os prazeres mundanos

Pois quanto mais o homem os comete

Mais o Senhor tem motivos

Para descansar no sétimo dia.

Quem perdeu a chave do Éden?...

Teria sido um homem pouco exigente

Ou seria um poeta feito exegeta?

Complicar... complicar... compre já

A fórmula do amor perfeito

Caso dê defeito

Acione o PROCOM

(Procuradoria da Comichão)

Porque afinal somos todos um pouco fingidores

De louco e de poeta

Cada um carrega seu trono

E ainda voa fora da asa.

\section{ÚLTIMO POEMA}

Sangro centelhas líquidas e dementes

Deságuo em uma mulher exposta ao seu holocausto

Absorvo-a em doses duplas de pecado

Sirvo-me no seu cálice rubro de recato.

Bebo-a em sacrifício silente

Mordo enseadas úmidas de metáforas

Extasio-me na tinta verde dos seus olhos tintos

Liquefaço-me em ritmos que a deliciam.

Gota a gota embebo-a em venenos

Retiro dela o mais puro antídoto

Que evapora nas dobras de um poema

Enquanto escrevo nela o dilema da minha poesia. 